\title{
EFFECT OF HFE GENE POLYMORPHISM ON SUSTAINED VIROLOGICAL RESPONSE IN PATIENTS WITH CHRONIC HEPATITIS C AND ELEVATED SERUM FERRITIN
}

\author{
Silvia COELHO-BORGES ${ }^{1,2}$, Hugo CHEINQUER ${ }^{1,2}$, Fernando Herz WOLFF',3,4, \\ Nelson CHEINQUER ${ }^{2}$, Luciano KRUG ${ }^{5}$ and Patricia ASHTON-PROLLA ${ }^{6,7}$
}

\begin{abstract}
Context - Abnormal serum ferritin levels are found in approximately $20 \%-30 \%$ of the patients with chronic hepatitis C and are associated with a lower response rate to interferon therapy. Objective - To determine if the presence of HFE gene mutations had any effect on the sustained virological response rate to interferon based therapy in chronic hepatitis $\mathrm{C}$ patients with elevated serum ferritin. Methods - A total of 44 treatment naïve patients with histologically demonstrated chronic hepatitis C, all infected with hepatitis $C$ virus genotype non-1 (38 genotype 3; 6 genotype 2 ) and serum ferritin above $500 \mathrm{ng} / \mathrm{mL}$ were treated with interferon (3 MU, 3 times a week) and ribavirin ( $1.000 \mathrm{mg}$, daily) for 24 weeks. Results - Sustained virological response was defined as negative qualitative HCV-RNA more than 24 weeks after the end of treatment. Serum HCV-RNA was measured by qualitative in house polymerase chain reaction with a limit of detection of $200 \mathrm{IU} / \mathrm{mL}$. HFE gene mutation was detected using restriction-enzyme digestion with RsaI (C282Y mutation analysis) and BclI (H63D mutation analysis) in 16 (37\%) patients, all heterozygous (11 H63D, $2 \mathrm{C} 282 \mathrm{Y}$ and 3 both). Sustained virological response was achieved in 0 of 16 patients with HFE gene mutations and $11(41 \%)$ of 27 patients without HFE gene mutations ( $P=0.002$; exact Fisher test). Conclusion - Heterozigozity for H63D and/or C282Y HFE gene mutation predicts absence of sustained virological response to combination treatment with interferon and ribavirin in patients with chronic hepatitis C, non-1 genotype and serum ferritin levels above $500 \mathrm{ng} / \mathrm{mL}$.
\end{abstract}

HEADINGS - Polymorphysm, genetic. Hepatitis C, chronic. Ferritins. Interferons.

\section{INTRODUCTION}

The Brazilian Public Health System provides antiviral treatment free of cost for selected patients with chronic hepatitis $\mathrm{C}$ virus (HCV) infection. Current government guidelines indicates 48 weeks of pegylated interferon (PEG-IFN) plus ribavirin (RBV) for patients with HCV genotype 1 and 24 weeks of conventional interferon (IFN) plus RBV for those with $\mathrm{HCV}$ genotypes 2 or $3^{(7)}$. Major predictive factors for sustained virological response (SVR) to IFN based treatment are well established for genotype 1 infected patients, including liver fibrosis stage, viral load, hepatic steatosis, body mass index, insulin resistance and IL-28 polymorphism ${ }^{(14,19)}$. However, predictive factors for SVR are not so clearly defined for genotypes 2 or 3 , since recent studies showed that viral load, insulin resistance and IL-28 polymorphism failed to predict SVR to IFN based therapy in these patients ${ }^{(30)}$.

Feder et al. ${ }^{(13)}$, in 1996, discovered the HFE gene and two of its polymorphisms, C282Y and H63D, which were clearly associated with higher prevalence of elevated serum ferritin, transferrin saturation, and genetic hemochromatosis. It is well known that $20 \%-30 \%$ of patients with chronic hepatitis $\mathrm{C}$ have serum markers of iron overload, but not an increased prevalence of HFE polymorphisms ${ }^{(4,5,10)}$. Elevated serum ferritin has long been recognized as a marker of poor response to antiviral treatment in chronic HCV infected patients ${ }^{(3,12,16)}$, however the mechanism underlying this effect is not clear and the role of HFE polymorphisms has not yet been established. Interestingly, there is intriguing evidence of an association between HFE polymorphism and higher SVR rates ${ }^{(8,31)}$, but this issue has not been specifically investigated among

\footnotetext{
All authors had access to the data, were actively involved in its analysis and interpretation, and approved the final manuscript. The authors declare no conflict of interest concerning the present article.

1 Graduate Program in Medicine: Gastroenterology - Faculdade de Medicina, Universidade Federal do Rio Grande do Sul (UFRGS) ${ }^{2}$ Gastroenterology Department, Hospital de Clínicas de Porto Alegre; ${ }^{3}$ Graduate Program in Epidemiology - Faculdade de Medicina, UFRGS; ${ }^{4}$ National Institute of Science and Technology for Health Technology Assessment (IATS) CNPq/Brazil; ${ }^{5}$ Amplicon - Molecular Biology Laboratory; ${ }^{6}$ Medical Genetics Service, Hospital de Clínicas de Porto Alegre; ${ }^{7}$ Genetics Department, UFRGS, Porto Alegre, RS, Brasil.

Correspondence: Dr. Fernando Herz Wolff - Rua Dr. Freire Alemão, 351/703 - 90450-060 - Porto Alegre, RS, Brazil. E-mail: fhwolff@gmail.com; silvia.cb@terra.com.br
} 
HCV patients with high serum ferritin, which are recognized as having difficult to treat disease.

Thus, the aim of the present study was to verify the prevalence of HFE gene polymorphisms and its impact on SVR rates among patients with HCV genotypes 2 or 3 and elevated serum ferritin treated with IFN/RBV in the setting of the Brazilian Public Health System. The finding of a reliable predictor of treatment outcome in the present study could help to improve government guidelines and refine treatment strategies, saving costs and avoiding futile therapy.

\section{METHODS}

\section{Study design}

A historical cohort study was conducted to evaluate the association between HFE gene polymorphisms and the response rate to IFN/RBV, using a cross-sectional design. The study was conducted in accordance with the ethics principles of the Declaration of Helsinki and was consistent with Good Clinical Practice guidelines, being approved by appropriate Institutional Review Boards. Written informed consent was obtained from all patients. All authors had access to the data, were actively involved in its analysis and interpretation, and approved the final manuscript.

\section{Patients}

Forty-four patients were recruited from the Viral Hepatitis Outpatient Clinic of Hospital de Clínicas de Porto Alegre, RS, Brazil a tertiary care institution in Porto Alegre, South of Brazil. Key inclusion criteria were: age equal or above 18 years old, detectable HCV RNA by polymerase chain reaction (PCR; Roche Amplicor; lower limit of detection: $50 \mathrm{IU} / \mathrm{mL}$ ), liver biopsy consistent with the diagnosis of chronic hepatitis $\mathrm{C} 1$ year or less before treatment start, baseline serum ferritin above $500 \mathrm{ng} / \mathrm{mL}, \mathrm{HCV}$ genotype 2 or 3 infection, complete treatment with IFN 3 MU 3 times a week plus RBV 1000 $\mathrm{mg}$ daily for 24 weeks with compliance equal or above $80 \%$ of the IFN/RBV dose and intended duration (80/80/80 rule), with a valid PCR result after 6 months of follow-up to establish the occurrence or not of SVR. Demographic data was collected at baseline. Biochemical and haematological parameters were assessed at baseline and every 4 weeks during treatment, and 24 weeks after the end of therapy. Patients with cirrhosis were eligible provided that they had compensated liver disease (Child-Pugh A). Main exclusion criteria were: co-infection with human immune deficiency virus and/or hepatitis B virus, liver disease attributable to a cause other than $\mathrm{HCV}$ infection, ultrasound compatible with hepatocellular carcinoma, and suboptimal IFN/RBV treatment (less than $80 \%$ of the expected IFN/RBV dose and/ or less than $80 \%$ of the intended treatment duration).

The study was approved by the ethics committee of the Hospital de Clínicas de Porto Alegre (2004).

\section{Exposure and outcomes}

HFE gene mutations were determined using restriction fragment lenght polymorphism. Patients were considered exposed if heterozygous or homozygous for $\mathrm{C} 282 \mathrm{Y}$ and/or H63D HFE polymorphisms. Primary outcomes were the rate of end of treatment virological response (EoTVR) and SVR between exposed and non-exposed, defined as undetectable HCV RNA by qualitative PCR assay at the end of treatment and after 24-weeks of follow-up, respectively. Co-primary outcome was the degree of liver fibrosis between exposed and non-exposed, assessed by an experienced pathologist using Metavir score, with cirrhosis considered as Metavir F3 or F4. Hepatic iron deposition was estimated using standard Perls iron stain protocol.

\section{Statistical Methods}

Patients were grouped as positive or negative for HFE gene mutations. Differences in baseline characteristics and outcomes between patients with and without HFE gene mutations were examined by Fisher's exact test (categorical variables), and Kruskall-Wallis (continuous variables). All statistical tests were two-sided and a $P$-value below 0.05 was considered significant. The Statistical Package for the Social Sciences (SPSS 13.0, Chicago, IL) was used for statistical analyses.

\section{RESULTS}

Among the 44 included patients, $40(90.9 \%)$ were male, all were caucasians, with a mean age of $48.4 \pm 7.7$ years (range 26-63). Thirty-eight were HCV genotype $3(86.4 \%)$ and 6 genotype $2(13.6 \%)$. Metavir fibrosis score was distributed as follows: F0 ( $=2) ; \mathrm{F} 1(\mathrm{n}=8) ; \mathrm{F} 2(\mathrm{n}=1) ; \mathrm{F} 3(\mathrm{n}=5)$ and $\mathrm{F} 4(\mathrm{n}=28)$. Distribution of iron in the liver was restricted to Kuppffer cells, ranging from absent to moderate deposition, with no histological diagnosis of hemochromatosis. Overall, mean baseline serum ferritin was $1.097 \mathrm{ng} / \mathrm{mL}$ (standard deviation \pm 552 ; range 500-2.865). Mean baseline serum transferrin saturation was $50.5 \%$ (standard deviation \pm 17.7 ; range $25 \%-86 \%$ ). All patients had elevated baseline serum ALT, with a mean value of $229.6 \mathrm{UI} / \mathrm{mL}$ (standard deviation \pm 120.3; range 55-516). HFE gene mutations were detected in 16 patients $(36 \%)$, with the following distribution: heterozygous H63D ( $n=11)$; heterozygous C282Y ( $n=2)$, and compound heterozygous H63D plus C282Y $(n=3)$. No patient was homozygous for any of the studied mutations. EoTVR and SVR were observed in $22(50 \%)$ and $11(25 \%)$ of the 44 treated patients, respectively. Comparison of demographic and disease characteristics between patients with versus without HFE gene mutations are depicted in Table 1.

\section{DISCUSSION}

In this study we found an overall SVR rate of $25 \%$ among patients with genotype 2 and 3. Remarkably, none of the 16 patients with HFE polymorphisms achieved SVR as opposed to $39 \%$ observed among the 28 individuals without this genetic marker. Although our SVR rates were lower than the 64\%-79\% reported in the IFN/RBV registration trials for HCV genotypes 2 and $3^{(15,27)}$ it was similar to that obtained in other Brazilian 
Coelho-Borges S, Cheinquer H, Wolff FH, Cheinquer N, Krug L, Ashton-Prolla P. Effect of HFE gene polymorphism on sustained virological response in patients with chronic hepatitis $\mathrm{C}$ and elevated serum ferritin

TABLE 1. Characteristics of the 44 patients according to HFE gene polymorphisms status

\begin{tabular}{|c|c|c|c|}
\hline & $\begin{array}{l}\text { With HFE polymorphisms } \\
\qquad(\mathrm{n}=16)\end{array}$ & $\begin{array}{l}\text { Without HFE polymorphisms } \\
\qquad(\mathrm{n}=28)\end{array}$ & $P$-value \\
\hline Mean age \pm SD (years) & $50 \pm 6$ & $48 \pm 8$ & 0.33 \\
\hline Male gender, n (\%) & $15(94)$ & $25(89)$ & 0.54 \\
\hline HCV genotype $3, \mathrm{n}(\%)$ & $14(88)$ & $24(86)$ & 0.62 \\
\hline Baseline serum ALT $\pm \mathrm{SD}(\mathrm{UI} / \mathrm{mL})$ & $221 \pm 88$ & $239 \pm 138$ & 0.66 \\
\hline Baseline serum ferritin $\pm \mathrm{SD}(\mathrm{ng} / \mathrm{dL})$ & $1.171 \pm 587$ & $1.060 \pm 546$ & 0.68 \\
\hline Baseline serum $\mathrm{TS} \pm \mathrm{SD}(\%)$ & $57 \pm 18$ & $46 \pm 17$ & 0.05 \\
\hline Cirrhosis (metavir F3/F4), n (\%) & $12(75)$ & $21(75)$ & 1.0 \\
\hline EOT virological response, n (\%) & $4(25)$ & $18(64)$ & 0.03 \\
\hline Sustained virological response, n (\%) & 0 & $11(39)$ & 0.003 \\
\hline
\end{tabular}

SD: standard deviation; HCV: hepatitis C virus; ALT: alanine aminotransferase; TS: transferrin saturation; EOT: end of treatment

studies that included real life cohorts. Indeed, a retrospective analysis of 173 patients with genotype 2 or 3 treated with conventional interferon alpha and ribavirin in the Public Health System of the State of Rio Grande do Sul, Brazil, showed an overall SVR rate of only $39 \%{ }^{(1)}$.

The lower SVR found in the present study could also be related to some characteristics of our cohort, namely the fact that $75 \%$ of the patients presented with advanced fibrosis and that only those with elevated serum ferritin at baseline were included. The reason for including only patients with serum ferritin levels above $500 \mathrm{ng} / \mathrm{dL}$ was to select genotypes 2 and 3 patients with really difficult to treat disease. Since transferring saturation was not available for all patients, serum ferritin level above $500 \mathrm{ng} / \mathrm{dL}$ was also the best available marker for iron overload, despite the fact that, in this situation, less than $10 \%$ of patients are expected to have a genetic iron overload disorder ${ }^{(20)}$. Individuals with treatment compliance outside the 80/80/80 rule were excluded to avoid introducing confounding factors such as dose reduction or treatment interruption, which could bias any potential relationship between SVR and HFE gene polymorphisms.

There was significantly higher serum transferring saturation among individuals with HFE polymorphism, despite no difference in serum ferritin levels. However, the absence of SVR observed in the group of individuals with this genetic marker was probably not directly related to iron overload, since most studies, so far, failed to report a significant difference in hepatic iron concentration between HCV patients with or without SVR after IFN/RBV treatment ${ }^{(23,25,29,33)}$. Moreover, therapeutic phlebotomies generally did not increase SVR, indicating that reduction of body iron stores was not associated with treatment outcome ${ }^{(11,21)}$.

It is possible that ferritin, as an acute phase reactant, behave as a marker of more active and advanced liver disease, instead of representing body iron content. In this regard, it has been reported that patients with chronic hepatitis $\mathrm{C}$ and high serum ferritin have significantly more liver inflammation and fibrosis compared to those with normal serum ferritin values ${ }^{(2,3,35)}$. This finding could explain the fact that the majority of our patients were cirrhotic. The recent finding of more rapid fibrosis progression among patients with chronic hepatitis $\mathrm{C}$ infected with $\mathrm{HCV}$ genotype 3 could also explain the high percentage of those with advanced disease in our cohort, since almost $90 \%$ of our patients had this genotype ${ }^{(9)}$. There was no patient with hemochromatosis in the present study, further supporting the fact that the mere presence of high serum ferritin in $\mathrm{HCV}$ infected patients does not necessarily correlates with condition.

Data on the possible relationship between carriage of the HFE gene mutations and response to IFN based therapy have been controversial ${ }^{(5,22,24,32,35,37)}$. Previous studies showed an association between H63D HFE polymorphism and higher SVR rates in patients with chronic hepatitis $C^{(6)}$.This relationship could be due to the fact that the HFE gene is located on the short arm of chromosome 6 , close to the major histocompatibility complex (MHC). In this regard, it is well known that MHC genes encode the human leukocyte antigens, which are important in antigen presentation and regulation of CD8 + and CD4 + T cells ${ }^{(18,34)}$. Previous studies have shown an impact of MHC gene variants and response to therapy in chronic $\mathrm{HCV}$ infection ${ }^{(17,28,31,36)}$.

Our finding contradicts the previously described association between H63D mutation and higher SVR ${ }^{(6)}$. The most seemingly explanation for the negative effect of $\mathrm{HFE}$ on SVR seen in the present study might be related to the unique characteristics of our cohort, comprised exclusively of individuals infected with genotype non-1 with elevated serum ferritin levels. It is also possible that HFE mutations, when associated with markers of iron overload such as serum ferritin and/or transferrin saturation, behave differently in respect to its gene expression profile.

If our results prove to be correct in future studies with larger samples and a prospective design, it could have a major impact on current Brazilian Guidelines, which still indicates IFN/RBV as first line therapy for HCV patients infected with genotypes 2 or 3 . Indeed, PEG-IFN/RBV is only offered as initial therapy to $\mathrm{HCV}$ genotype 1 carriers and as second line therapy in HCV non-1 genotypes after failure of IFN/RBV. The finding of HFE polymorphism as a strong predictor of non-response in our sample should lead to further studies in order to better clarify if the negative impact of HFE on SVR of patients with genotypes 2 or 
3 and high serum ferritin could be neutralized using more potent therapy.

The limitations of the present study have to be addressed, and are mainly related to the relative small sample size, retrospective design and absence of other predictors of response to therapy, such as viral load and IL-28B. Nevertheless, it is the only study conducted so far in this patient population chronically infected with $\mathrm{HCV}$ genotypes 2 and 3 with high serum ferritin. Moreover, both viral load and IL-28B do not seem to have a major impact on SVR in the majority of non-1 HCV genotypes ${ }^{(26)}$. Finally, we believe the relationship between HFE mutations and absence of SVR in this cohort merits future research to clarify this seemingly important association.

Coelho-Borges S, Cheinquer H, Wolff FH, Cheinquer N, Krug L, Ashton-Prolla P. Efeito do polimorfismo do gene HFE sobre a resposta viral sustentada em portadores de hepatite crônica C com ferritina sérica elevada. Arq Gastroenterol. 2011;49(1):9-13.

RESUMO - Contexto - Níveis séricos anormais de ferritina são encontrados em aproximadamente 20\%-30\% dos pacientes com hepatite crônica C e estão associadas a uma baixa taxa de resposta à terapia com interferon. Objetivo - Avaliar a associação entre a presença de mutações do gene HFE e a taxa de resposta virológica sustentada ao interferon em pacientes portadores de hepatite crônica C com ferritina sérica elevada. Métodos - Um total de 44 pacientes, virgem de tratamento, infectado pelo vírus da hepatite C de genótipos não-1 (38 genótipo 3; 6 genótipo 2) e ferritina sérica acima de $500 \mathrm{ng} / \mathrm{mL}$ foi tratado com interferon (3 MU, três vezes por semana) e ribavirina (1000 mg/dia) por 24 semanas. Resposta virológica sustentada foi definida como HCV-RNA indetectável 24 semanas após o fim do tratamento. Foi utilizado técnica de reação em cadeia da polimerase em tempo-real com limite de detecção de 200 UI /mL. Resultados - Mutações do gene HFE foram detectadas por "restriction-enzyme digestion" com RsaI (análise de mutação C282Y) e BclI (análise de mutação H63D) em 16 pacientes (37\%), todos heterozigotos (11 H63D, 2 C282Y e 3 ambos). Resposta virológica sustentada foi alcançada em 0 de 16 pacientes com mutações do gene HFE e 11 (41\%) dos 27 pacientes sem mutações do gene HFE ( $P=0,002$; teste exato de Fisher). Conclusão - A heterozigose para os genes H63D e/ou C282Y HFE está associada à redução significativa da taxa de resposta virológica sustentada ao tratamento com interferon e ribavirina em pacientes com hepatite crônica $\mathrm{C}$, genótipo não-1 e com níveis séricos de ferritina acima de $500 \mathrm{ng} / \mathrm{mL}$.

DESCRITORES - Polimorfismo genético. Hepatite C crônica. Ferritinas. Interferons.

\section{REFERENCES}

1. Alves AV, de Azevedo AP, Perin C, Ramos GZ, Brandão AB, de Mattos AA, de Almeida PR. [Interferon-alpha and ribavirin therapy on chronic hepatitis $\mathrm{C}$ virus infection: the experience of Rio Grande do Sul State Health Department, Brazil]. Arq Gastroenterol. 2003;40:227-32.

2. Beinker NK, Voigt MD, Arendse M, Smit J, Stander IA, Kirsch RE. Threshold effect of liver iron content on hepatic inflammation and fibrosis in hepatitis B and C. J Hepatol. 1996;25:633-8.

3. Bonkovsky HL, Banner BF, Rothman AL. Iron and chronic viral hepatitis Hepatology. 1997;25:759-68.

4. Bonkovsky HL. Iron as a comorbid factor in chronic viral hepatitis. Am J Gastroenterol. 2002;97:1-4.

5. Bonkovsky HL, Troy N, McNeal K, Banner BF, Sharma A, Obando J, Mehta S, Koff RS, Liu Q, Hsieh CC. Iron and HFE or TfR1 mutations as comorbid factors for development and progression of chronic hepatitis C. J Hepatol. 2002;37:848-54.

6. Bonkovsky HL, Naishadham D, Lambrecht RW, Chung RT, Hoefs JC, Nash SR, Rogers TE, Banner BF, Sterling RK, Donovan JA, Fontana RJ, Di Bisceglie AM, Ghany MG, Morishima C; HALT-C Trial Group. Roles of iron and HFE mutations on severity and response to therapy during retreatment of advanced chronic hepatitis C. Gastroenterology. 2006;131:1440-51.

7. Brasil. Secretaria de Vigilância em Saúde. Portaria 34 de 28 de setembro de 2007 Dispõe sobre protocolo clínico e diretrizes terapêuticas para hepatite viral C. Brasília: Ministério da Saúde; 2007.

8. Carneiro MV, Souza FF, Teixeira AC, Figueiredo JF, Villanova MG, Secaf M, Passos AD, Ramalho LN, Carneiro FP, Zucoloto S, Candolo Martinelli AL. The H63D genetic variant of the HFE gene is independently associated with the virological response to interferon and ribavirin therapy in chronic hepatitis $\mathrm{C}$. Eur J Gastroenterol Hepatol. 2010;22:1204-10.

9. De Nicola S, Aghemo A, Rumi MG, Colombo M. HCV genotype 3: an independent predictor of fibrosis progression in chronic hepatitis C. J Hepatol. 2009;51:964-6

10. Di Bisceglie AM, Axiotis CA, Hoofnagle JH, Bacon BR. Measurements of iron status in patients with chronic hepatitis. Gastroenterology. 1992;102:2108-13.

11. Di Bisceglie AM, Bonkovsky HL, Chopra S, Flamm S, Reddy RK, Grace N, Killenberg P, Hunt C, Tamburro C, Tavill AS, Ferguson R, Krawitt E, Banner B,
Bacon BR. Iron reduction as an adjuvant to interferon therapy in patients with chronic hepatitis $\mathrm{C}$ who have previously not responded to interferon: a multicenter, prospective, randomized, controlled trial. Hepatology. 2000;32:135-8.

12. Distante S, Bjøro K, Hellum KB, Myrvang B, Berg JP, Skaug K, Raknerud N, Bell H. Raised serum ferritin predicts non-response to interferon and ribavirin treatment in patients with chronic hepatitis $\mathrm{C}$ infection. Liver. 2002, 22:269-75.

13. Feder JN, Gnirke A, Thomas W, Tsuchihashi Z, Ruddy DA, Basava A, Dormishian F, Domingo R Jr, Ellis MC, Fullan A, Hinton LM, Jones NL, Kimmel BE, Kronmal GS, Lauer P, Lee VK, Loeb DB, Mapa FA, McClelland E, Meyer NC, Mintie GA, Moeller N, Moore T, Morikang E, Prass CE, Quintana L, Starnes SM, Schatzman RC, Brunke KJ, Drayna DT, Risch NJ, Bacon BR, Wolff RK. A novel MHC class I-like gene is mutated in patients with hereditary haemochromatosis. Nat Genet. 1996;13:399-408.

14. Ferenci P. Predictors of response to therapy for chronic hepatitis C. Semin Live Dis. 2004;24:25-31

15. Fried MW, Shiffman ML, Reddy KR, Smith C, Marinos G, Gonçales FL Jr, Häussinger D, Diago M, Carosi G, Dhumeaux D, Craxi A, Lin A, Hoffman J, Yu J. Peginterferon alfa-2a plus ribavirin for chronic hepatitis $\mathrm{C}$ virus infection. N Engl J Med. 2002;347:975-82.

16. Fujita N, Sugimoto R, Urawa N, Araki J, Mifuji R, Yamamoto M, Horiike S, Tanaka H, Iwasa M, Kobayashi Y, Adachi Y, Kaito M. Hepatic iron accumulation is associated with disease progression and resistance to interferon/ribavirin combination therapy in chronic hepatitis C. J Gastroenterol Hepatol. 2007;22:1886-93.

17. Fuller MJ, Shoukry NH, Gushima T, Bowen DG, Callendret B, Campbell KJ, Hasselschwert DL, Hughes AL, Walker CM. Selection-driven immune escape is not a significant factor in the failure of CD4 $\mathrm{T}$ cell responses in persistent hepatitis $\mathrm{C}$ virus infection. Hepatology. 2010;51:378-87.

18. Gerhard GS, Ten Elshof AE, Chorney MJ. Hereditary haemochromatosis as an immunological disease. Br J Haematol. 1998;100:247-55

19. Hayes CN, Kobayashi M, Akuta N, Suzuki F, Kumada H, Abe H, Miki D, Imamura M, Ochi H, Kamatani N, Nakamura Y, Chayama K. HCV substitutions and IL28B polymorphisms on outcome of peg-interferon plus ribavirin combination therapy. Gut. 2011;60:261-7.

20. Hearnshaw S, Thompson NP, McGill A. The epidemiology of hyperferritinaemia World J Gastroenterol. 2006;12:5866-9. 
21. Herrera JL. Iron depletion is not effective in inducing a virologic response in patients with chronic hepatitis $\mathrm{C}$ who failed to respond to interferon therapy. Am J Gastroenterol. 1999;94:3571-5.

22. Hézode C, Cazeneuve C, Coué O, Roudot-Thoraval F, Lonjon I, Bastie A, Duvoux C, Pawlotsky JM, Zafrani ES, Amselem S, Dhumeaux D. Liver iron accumulation in patients with chronic active hepatitis $\mathrm{C}$ : prevalence and role of hemochromatosis gene mutations and relationship with hepatic histological lesions. J Hepatol. 1999;31:979-84.

23. Hofer H, Osterreicher C, Jessner W, Penz M, Steindl-Munda P, Wrba F, Ferenci P. Hepatic iron concentration does not predict response to standard and pegylated-IFN/ribavirin therapy in patients with chronic hepatitis C. J Hepatol. 2004;40:1018-22.

24. Kazemi-Shirazi L, Datz C, Maier-Dobersberger T, Kaserer K, Hackl F, Polli C, Steindl $\mathrm{PE}$, Penner E, Ferenci P. The relation of iron status and hemochromatosis gene mutations in patients with chronic hepatitis C. Gastroenterology. 1999;116:127-34.

25. Lebray P, Zylberberg H, Hue S, Poulet B, Carnot F, Martin S, Chretien Y, Pol S, Caillat-Zuckman S, Bréchot C, Nalpas B. Influence of HFE gene polymorphism on the progression and treatment of chronic hepatitis $\mathrm{C}$. J Viral Hepat. 2004; 11:175-82.

26. Mangia A, Thompson AJ, Santoro R, Piazzolla V, Tillmann HL, Patel K, Shianna KV, Mottola L, Petruzzellis D, Bacca D, Carretta V, Minerva N, Goldstein DB, McHutchison JG. An IL28B polymorphism determines treatment response of hepatitis $\mathrm{C}$ virus genotype 2 or 3 patients who do not achieve a rapid virologic response. Gastroenterology. 2010;139:821-7.

27. Manns MP, McHutchison JG, Gordon SC, Rustgi VK, Shiffman M, Reindollar R, Goodman ZD, Koury K, Ling M, Albrecht JK. Peginterferon alfa-2b plus ribavirin compared with interferon alfa-2b plus ribavirin for initial treatment of chronic hepatitis C: a randomised trial. Lancet. 2001;358:958-65.

28. Neumann-Haefelin C, Spangenberg HC, Blum HE, Thimme R. Host and viral factors contributing to CD8+ T cell failure in hepatitis $\mathrm{C}$ virus infection. World J Gastroenterol. 2007;13:4839-47.

29. Pianko S, McHutchison JG, Gordon SC, Heaton S, Goodman ZD, Patel K, Cortese CM, Brunt EM, Bacon BR, Blatt LM. Hepatic iron concentration does not influence response to therapy with interferon plus ribavirin in chronic HCV infection. J Interferon Cytokine Res. 2002;22:483-9.
30. Rauch A, Kutalik Z, Descombes P, Cai T, Di Iulio J, Mueller T, Bochud M, Battegay M, Bernasconi E, Borovicka J, Colombo S, Cerny A, Dufour JF, Furrer H, Günthard HF, Heim M, Hirschel B, Malinverni R, Moradpour D, Müllhaupt B, Witteck A, Beckmann JS, Berg T, Bergmann S, Negro F, Telenti A, Bochud PY; Swiss Hepatitis C Cohort Study; Swiss HIV Cohort Study. Genetic variation in IL28B is associated with chronic hepatitis C and treatment failure: a genome-wide association study. Gastroenterology. 2010;138:1338-45.

31. Rhodes SL, Erlich H, Im KA, Wang J, Li J, Bugawan T, Jeffers L, Tong X, Su X, Rosen HR, Yee LJ, Liang TJ, Yang H; Virahep-C Study Group. Association between the human $\mathrm{MHC}$ and sustained virologic response in the treatment of chronic hepatitis C virus infection. Genes Immun. 2008;9:328-33.

32. Smith BC, Gorve J, Guzail MA, Day CP, Daly AK, Burt AD, Bassendine MF Heterozygosity for hereditary hemochromatosis is associated with more fibrosis in chronic hepatitis C. Hepatology. 1998;27:1695-9.

33. Souza RM, Freitas LA, Lyra AC, Moraes CF, Braga EL, Lyra LG. Effect of iron overload on the severity of liver histologic alterations and on the response to interferon and ribavirin therapy of patients with hepatitis $\mathrm{C}$ infection. Braz J Med Biol Res. 2006;39:79-83.

34. Ten Elshof AE, Brittenham GM, Chorney KA, Page MJ, Gerhard G, Cable EE, Chorney MJ. Gamma delta intraepithelial lymphocytes drive tumor necrosis factoralpha responsiveness to intestinal iron challenge: relevance to hemochromatosis. Immunol Rev. 1999; 167:223-32.

35. Thorburn D, Curry G, Spooner R, Spence E, Oien K, Halls D, Fox R, McCruden EA, MacSween RN, Mills PR. The role of iron and haemochromatosis gene mutations in the progression of liver disease in chronic hepatitis C. Gut. 2002;50:248-52.

36. Tseng KC, Chang CK, Chou AL, Hsieh YH, Tseng CA, Lai NS. Prognostic effect of human leukocyte antigen class I and II alleles on chronic hepatitis C patients treated by pegylated interferon-alfa plus ribavirin in Taiwan. Hepatogastroenterology. 2010;57:456-61.

37. Tung BY, Emond MJ, Bronner MP, Raaka SD, Cotler SJ, Kowdley KV Hepatitis C, iron status, and disease severity: relationship with HFE mutations Gastroenterology.2003;124:318-26.

Received 25/4/2011 Accepted 10/8/2011. 